Business Ethics and Leadership, Volume 3, Issue 2, 2019

ISSN (online) - 2520-6311; ISSN (print) - 2520-6761

\title{
Deterministic Modeling for Evaluating Consumers' Attitude towards Telecommunication Service in Bangladesh
}

\author{
Meher Neger \\ Associate Professor, Department of Marketing, Cumilla University, Bangladesh
}

Md. Zakir Hossain Bhuiyan

Professor, Department of Marketing, University of Dhaka, Bangladesh

Md. Humayun Kabir Chowdhury

Professor, Department of Marketing, Jagannath University, Bangladesh

\section{Afzal Hossain}

Adjunct faculty, Department of Business Administration (Professional), Tejgaon College, Bangladesh

\begin{abstract}
This study is conducted empirically for measuring consumers' attitude towards telecommunication service in Bangladesh. A conceptual model has been developed based on two constructs. Telecommunication service related intrinsic and intrinsic constructs where five individual attributes (network availability, service quality, service charge strategies, offered value, brand image) are included. A series of analysis technique (arithmetic means) are used to find out the weighted average of intrinsic \& extrinsic attributes, which are considered by Bangladeshi consumers for using telecommunication service. Fishbein's Multiattribute Attitude Model has been used for measuring the overall attitude of consumers toward telecommunication service in Bangladesh, which could help for successful business operations, management, and long-term sustainability of attitude measurement in order to improve product or service quality as per consumer expectation level. A total of 840 respondents who have a direct role for receiving telecommunication service are selected on the basis of stratified random sampling to fill up the questionnaire where some of the information is gathered by using Likert and Semantic Differential scales. Data has been collected from the students of both (public and private) universities and professional of different categories (Universities Teachers, Different Businessmen, Banker, Corporate Officers, Housewives, and others Government, non-government employees) of Bangladesh through a set of a structured questionnaire. To measure the overall evaluation (ei) regarding the selected attributes for the specific firm rating scale ranging from extremely good to extremely bad $(+3$ to -3$)$ was used and asked to encircle the point to express their opinion. The respondents were also asked through the Seven Point scale ranging from 7 indicates very strongly believe, and 1 indicates very strongly disbelieve to know how strongly they believe that the individual firm of Bangladesh contains the said attributes. Findings of Fishbein's Multiattribute Attitude Model point out that the consumers' overall attitude towards Grameen phone Ltd. as the telecommunication service providing firm is higher than other selected firms in Bangladesh. That means, Grameen Phone Ltd. is viewed top most favorable position and Banglalink is the next position; Robi is the last position; among the three alternatives on the basis of said attributes. Consumers' solid knowledge and experiences about the product or service and their long-term observation and interactions have played an important role in the service sector. The implications of these findings can be applied to the enhancement of the competitive position of different telecommunication service providing firms in a competitive market of Bangladesh. From a research perspective, the study suggests fruitful research directions for further research by others.
\end{abstract}

Keywords: consumer attitude, Fishbein's Multiattribute Attitude Model, salient belief.

JEL Classification: L96, O32, Q55.

Cite as: Neger, M., Bhuiyan, Md. Z. H., Chowdhury, Md. H. K., Hossain, A. (2019). Deterministic Modeling for Evaluating Consumers' Attitude towards Telecommunication Service in Bangladesh. Business Ethics and Leadership, 3(2), 72-82. http://doi.org/10.21272/bel.3(2).72-82.2019.

(C) The Authors, 2019. This article is published with open access at Sumy State University.

\section{Introduction}

The concept of consumer attitude is one of the most important concepts in the study of consumer behavior. Many firms are spending millions of dollars researching consumers' attitude toward their products and brands. 
The term consumers' attitudes are a composite of a consumer belief, feelings and behavioral intentions towards the object. It is an enduring organization of motivational, emotional, perceptual, and cognitive process with respect to some aspect of the individual's world. It is related to the intention to buy a product or service. The attitude of consumers towards any product or service is the vital influencer in buying behavior. The target of a company in attracting its consumers' is to create consumers favorable attitude. Like many other companies, telecommunication companies are trying to capture high market share by creating favorable consumer attitude. This study is conducted to find out the overall attitude of consumers towards telecommunication service in Bangladesh and to see how these are influenced by the total attributes of the product or service. The consumers make decisions about the quality of products or services based on a systematic process of acquisition, evaluation and integration of product or service cues. A cue is defined as all informational stimuli available to the consumer before consumption (Monroe and Krishnan, 1976), and it can be intrinsic or extrinsic. Telecommunication service related intrinsic and extrinsic constructs are network availability, service quality, service charge strategies, brand image, offered value and so on. These features are essential from a marketing perspective as they can have different important influences on the attitude of consumers toward a product or service. With the help of the overall attitude toward the service, marketers can implement appropriate marketing strategies to achieve market share.

However, in recent times telecommunication makes the whole world in a small village by using the service life become more comfortable and easier. It helps us in the field of business, official function, personal communication, recreation, space station and so on. As people of the third world country, consumers are very much price conscious but simultaneously they consider the quality of the product or service. The quality of the product or service can increase with adding intrinsic attributes as well as increasing the image of extrinsic attributes. Consumers' basically expect desired service from the telecommunication service providing firms. The study is conducted to find out the consumers' attitude towards telecommunicating service in Bangladesh on the basis of intrinsic and extrinsic cues of telecommunication service. The paper is organized as follows: Section 1 focuses on introductory issues, Section 2 represents the statement of the problem, Sections 3 reviews the relevant literature to attitude of the consumer, and each of the proposed constructs, Section 4 the research objectives are defined, Section 5 observes details of the model and conceptual framework of the study are also presented, Section 6 discusses the methodology of the study, Section 7 depicts the findings of the study, Section 8 describes the recommendations and conclusion, finally, limitations of the study and future research directions are presented in Section 9.

\section{Statement of the Problem}

Product or service quality always depends on different trivial attributes. The image attributes incorporated were based on the service categories, situations and benefits offered. While mentioning the service quality for an image attribute was positively related to a future purchase, this relationship did not vary from one to another service providing organization.

The more attributes of product/service associated with the greater likelihood of the consumer will think and therefore consider the service providing firm for receiving the services and the service firm will be acceptable or any criteria used. The long-term aim is to select a suitable firm for any number of attributes likely to be used by the consumer. This is not investigated carefully for Telecommunication Company in our country, which should be investigated with higher priority and care.

However, even though studies on attitudes measurement of consumers towards telecommunication service has been conducted from various perspectives, the dynamic complex natures of the factors of attitudes, especially, firm selection of consumers' and their opinions about attribute preferences and competitive strategies have not been clearly addressed in Bangladesh. So, the study has been empirically tested its relevant components from the perspectives of Bangladeshi consumers. Therefore, the information from this study can help policy-makers and planners to build a more competitive brand in the market choice.

\section{Literature Review \& Research Gap}

The section has been provided a review of the relevant literature from where we can find out the research gap. Some selected reviews have been presented below to find out the specific research gap.

Anderson, et al. (2004) objective was to test a simple structural model relating attitude toward business to product satisfaction, experience, and search effort. Automobiles were selected to measure attitude towards business. The confirmatory factor analysis (CoFAMM) and the LISREL model were used to test the hypotheses. All hypotheses of the model were supported. The relationships between business attitude and search effort are 
negative. A major disadvantage of those models is that large samples sizes are required. It is time and cost constraints for the researcher.

Mohana Prasad and Dr. D. Prasanna Kumar (2016) objective was that factors influencing the behavior of the mobile phone users to switch their service providers Andhra Pradesh. They concluded that there are different factors which affect the customers to switch from loyalty to switching intensions such as price, service quality, technology change, social influence, switching cost, and advertising. The results show that the cellular service providers pay attention to all factors and especially towards the price of the services because the consumers' switching intensions were found to be most significantly influenced by the price.

The study "Attitude of Owners, Managers, and Workers: A Case Study in Bangladesh" conducted by Taher (1998), is based on the attitudes of the owners, managers and workers of some selected companies in Bangladesh. It highlights some issues like technology transfer, feeling of the respondents on managerial factors, responsibilities of personnel and also production-oriented phenomena. Basically, the study has measured the attitude of the respondents to various aspects from a psychological point of view. For measuring the attitudes, the rating scale was applied. It is noted that the study was not comparative in nature between the conventional and the Islamic banks.

Neger, M. (2011) objective was to measure consumer attitude towards internet service. As the stimuli internet service was selected. A conceptual model was developed based on intrinsic and extrinsic attributes of internet service which effect on the attitude of consumers. Here Fishbein's Multi-attributes attitude model was used to measure the attitude. The result of the study was that all of the hypotheses were supported so, product/service related intrinsic cues where included three individual attributes i.e. easy access, seamless connectivity, freedom of service and extrinsic cues where also included three individual attributes i.e. guaranty/warranty, reasonable service charge, brand image that served to influence consumer's attitude toward internet service.

Umar Salisu \& I.Y. Emmanuel (2014) objective was that Telecommunications and Economic Performance in Nigeria. The paper sets out to examine the separate effects of the reform and the reformed telecommunications on the various measures of economic performance. The researchers estimated the Modified Engle-Granger Cointegration test that allows for a structural break using Nigeria's data for the period 1984-2011. The results of this model show that the reform and the reformed telecommunications have significant effects on economic performance. They recommended that the regulatory body showed concentrate more efforts in designing and improving good institutions that will enable the maximum benefits from telecommunications to be derived.

Ernest Emeka Izogo (2017) objective was that customer loyalty in the telecom service sector. The paper examines how firms can influence customer loyalty through customer commitment by leveraging two constructs of service quality. The analysis is based on 138 responses retrieved from experience user of mobile phone services in one of the big cities in the South Eastern part of Nigeria through a survey questionnaire. The validity and reliability of the measurement model, as well as the proposed hypotheses, were examined through the Partial Least Square Structural Equation modeling procedure. Findings-service readability is a direct predictor of customer loyalty while service assurance is not.

Neger, M. (2018) objective was to measure consumers' attitude towards brand switching on the telecommunication sector in Bangladesh. As the stimuli, telecommunication service was selected. Tricomponent Attitude model, Fishbein's Multi-attributes attitude model, Logistic Regression model and Markov chain were used to measure the variables. Telecommunication service related intrinsic and extrinsic cues where five individual attributes are included i.e. network availability, service quality, service charge strategies, brand image, offered value that served to influence consumer's attitude and some influential factors i.e. strong advertisement policy, huge offering packages, perception about network coverage, FnF tariff and so on which influence on consumer to switch from one to another brand of telecommunication sector in Bangladesh. The major limitation of this study was that the study attempted to consider only three leading telecommunication firms. It would have been more representative if the total number of telecommunication service providing firms of Bangladesh could have been taken under this study.

Youssef Mehdipour and Hamideh Zerehkafi (2013) objective was that customers attitude toward mobile service providers in Hyderabad. This research article investigated the attitude of customers to mobile communication. All the customers of mobile service in Hyderabad city (Andhra Pradesh) constituted the population. Airtel, Vodafone, Idea, Cell- one are the four companies included in the study. The sample of the study was 2600 customers randomly selected. Results showed that Airtel has a major share in the market and among customers, Vodafone has a larger share than Airtel. Reasons like packages offered by Vodafone are 
attracting, which makes it have a large share. Services and network of Airtel are good compare to the other players in the market but it is Vodafone, which offers better packages. The major limitation of the study was that only the people in Andhra Pradesh of Hyderabad have been targeted. We could have extended our study to various areas and regions.

After reviewing some related literature, it is clear that maximum researchers tried to measure the consumers' attitude from the perspectives of foreign consumers, but this research has been tried to focus on this area from the perspectives of Bangladeshi consumers which remained as an unexplored field. Moreover, in Bangladesh, there is no depth research conducted yet so far in this regards. So, the study has been tried to fill up this gap by using intrinsic and extrinsic attributes (network availability, service quality, service charge strategies, offered value, brand image) for measuring consumer attitude towards telecommunication service in Bangladesh.

\section{Objectives of the Study}

The main objective of the study is to measure consumers' attitude towards telecommunication service in Bangladesh. The specific objectives of this study are, firstly, to find out the different attributes which are considered by Bangladeshi consumers while receiving telecommunication service; secondly, to measure the attitude of consumers towards telecommunication service based on Fishbein's Multi-attributes Attitude Model; and finally to highlight some suggestions to form positive attitude of Bangladeshi consumers towards telecommunication service and to protect the market share by telecommunication firms in the competitive market.

\section{Model Specification}

The section is observed details the model used in the study to fill up the research gap on the basis of literature review.

\subsection{Conceptual Model of the Study}

Attitudes cannot be directly observed because of their covert nature. In other words, an attitude is a predisposition to respond overtly and that this predisposition leads to actual overt behavior. Marketers stand to benefit from favorable consumer attitudes, as reflected in the consistency of consumer behaviors with respect to their brand (Kim, 2002).

Figure 1.1 indicates that product/service related attributes are divided into two broad categories, i.e; Intrinsic or Internal and Extrinsic or External and both attributes are influenced on forming the attitude of consumers.

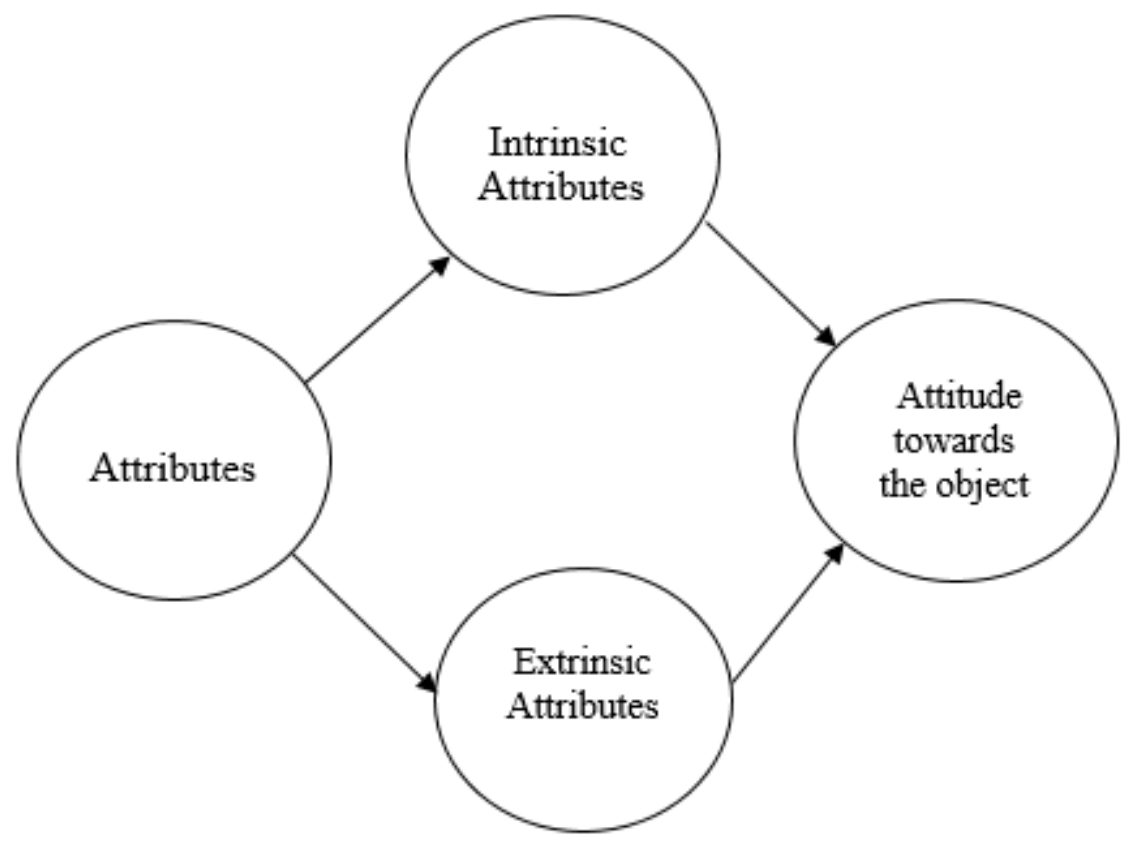

Figure 1.1 Proposed conceptual model for consumers' attitude towards telecommunication service 


\subsection{Fishbein's Multiattribute Attitude Model (FMAM)}

The key proposition in Fishbein's theory is that the evaluations of salient beliefs cause overall attitude. Simply stated, people tend to like objects that are associated with "good" characteristics and dislike the objects they believe have "bad" attributes. In Fishbein's Multiattribute model, overall attitude toward an object is a function of two factors: the strengths of the salient beliefs associated with the object and the evaluation of those beliefs.

Formally, the model proposes that: $\quad \mathrm{A}_{\mathrm{o}}=\sum_{i=1}^{n}$ biei

Where $\mathrm{A}_{\mathrm{o}}=$ attitude toward the object, $\mathrm{bi}=$ the strength of the salient belief that the object has attributed $\mathrm{i}$, ei $=$ the evaluation of attribute $\mathrm{i}, \mathrm{n}=$ the number of beliefs about the object (Fishbein, 1963). The model is used to examine the component beliefs that underlie consumer attitudes.

\section{Methodology of the Study}

This study examines how consumers form an attitude towards telecommunication service based on the evaluation of the salient beliefs of the consumers. The survey approach is used for this study. Details of the pretests, sample respondents, types of data, data collection method and data analysis procedures are discussed below.

\subsection{Pretest 1}

The purpose of the first pretest was to select the attributes that are considered by the consumer to receive the telecommunication service. The information cultivated among 100 respondents. When asked the subject about the attributes of telecommunication service that are basically considered for receiving the service, they replied 10 attributes. Among those attributes' that (up to 30\% and above) had been selected for the convenience of the study. The following table shows the attributes that are considered by the consumer while receiving the telecommunication service.

Table 1. Consumers' opinion for different attributes of telecommunication service

\begin{tabular}{|c|l|c|c|c|}
\hline No. & \multicolumn{1}{|c|}{ Attributes' Name } & T.R. & T.R.D & \% \\
\hline 1. & Network Availability & 100 & 75 & 75 \\
\hline 2. & Service Quality & 100 & 60 & 60 \\
\hline 3. & Service Charge Strategies & 100 & 45 & 45 \\
\hline 4. & Brand Image & 100 & 42 & 42 \\
\hline 5. & Offered Value & 100 & 40 & 40 \\
\hline 6. & Customer Care Service & 100 & 28 & 28 \\
\hline 7. & Guaranty / warranty & 100 & 22 & 22 \\
\hline 8. & Technical Excellence & 100 & 17 & 17 \\
\hline 9. & Un-Compromised Security & 100 & 10 & 10 \\
\hline 10. & Less Radiation & 100 & 06 & 06 \\
\hline
\end{tabular}

TR = Total Respondents, TRD = Total Respondents' Response

Source: Neger, M. (2018), PhD Thesis (unpublished)

From Table 1, it is found that network availability, service quality, service charge strategies, brand image, and offered value as opined by $75 \%, 60 \%, 45 \%, 42 \%, 40 \%$ respondents respectively. So, those five attributes bear up to $30 \%$ and above had been selected for the convenience of the final study.

\subsection{Pretest 2}

At present, there are six mobile phone operators offering their services to customers in Bangladesh. Among these, the firms having 30\% or above response out of total respondents have been selected for the convenience of the study. This information has been collected 100 respondents where approximately $70 \%$ are students of the tertiary levels and rests of the $30 \%$ are professionals. When the respondents were asked about the different telecommunication service providing firms, the name of 6 firms came to their mind at that moment. The following table shows the name of telecommunication service providing firms that are considered by the consumers: 
Table 2. Consumers' opinion on different telecommunication service providing firms, which are available in Bangladesh market

\begin{tabular}{|c|l|c|c|c|}
\hline No. & \multicolumn{1}{|c|}{ Firms' Name } & T.R. & T.R.D & \% \\
\hline 1. & Grameen Phone Ltd & 100 & 78 & 78 \\
\hline 2. & Banglalink & 100 & 71 & 71 \\
\hline 3. & Robi & 100 & 69 & 69 \\
\hline 4. & City Cell & 100 & 29 & 29 \\
\hline 5. & Airtel Bangladesh Ltd & 100 & 25 & 25 \\
\hline 6. & Teletalk Bangladesh Ltd & 100 & 22 & 22 \\
\hline
\end{tabular}

$\mathrm{TR}=$ Total Respondents, $\mathrm{TRD}=$ Total Respondents' Response

Source: Field Survey

From Table 2, it is found that Grameen Phone Ltd., Banglalink and Robi have got the highest importance that means those firms bearing up to $30 \%$ and above have been selected for the convenience of the study.

\subsection{Target Population}

The populations of this study are mainly students of the universities (Public and Private) and professionals of different categories (Universities Teachers, Different Businessmen, Bankers, Corporate officers, Housewives and other government, Non-government employees) who stay at Dhaka Metropolitan city; age 18 to 65 years, and they are the voice caller.

\subsection{Sampling Technique and Sample Size}

In this study the probability sampling technique (Stratified sampling) has been used on the basis of gender and profession of the customers, the desired sample size can be calculated on the basis of the following formula.

$\mathrm{n}_{\text {strat }}=\mathrm{D} \mathrm{X} \mathrm{n_{ \text {srs } }}$

Where, $\mathrm{n}_{\text {srs }}$ refers to sample size of simple random sampling

$\mathrm{n}_{\mathrm{srs}}=\frac{Z^{2} p q}{d^{2}}=\frac{(1.96)^{2} \times 0.47 \times 0.53}{(0.05)^{2}}=383$

Here, $\quad \mathrm{n}=$ required sample size;

$\mathrm{z}=$ standard value of 1.96 at $95 \%$ confidence level;

$\mathrm{d}=$ margin of error at $5 \%$ (standard value of 0.05 );

$\mathrm{p}=$ estimated proportion of Grameen Phone users;

$\mathrm{D}=$ refers design effect for stratified random sampling (say, $\mathrm{D}=2$ ).

So, required sample size 2 X $383=766$.

\subsection{Types of Data}

Both Primary and Secondary data have been used to get the actual findings of the study. Primary data has been collected from the field directly and secondary data has been collected from the published materials of different organization (BTRC, Grameen Phone Limited and others.)

\subsection{Data Collection Method and Procedures}

Data has been collected from students of the universities (Public and Private) and professionals of different categories through a set of a structured questionnaire. In the first page of the questionnaire, it has been well described the purpose of the study. After that, some introductory questions are incorporated into the questionnaire. In the next page of the questionnaire, the respondents have been asked to turn the page including information regarding the attributes of the individual brand, which influence to form the attitude of consumers towards the telecommunication sector in Bangladesh. To measure the belief (bi) of consumers regarding the selected attributes for the specific brand of telecommunication sector; Seven Point scale ranging from 7 indicates very strongly believe, and 1 indicates very strongly disbelieve has been used and asked to write the score to express their opinion. The semantic differential scale has been also used to measure the overall evaluation (ei) regarding the selected attributes for the specific brand rating scale ranging from extremely good to extremely bad ( +3 to -3 ) has been used and asked to encircle the point to express their opinion. 5 points 
ISSN (online) - 2520-6311; ISSN (print) - 2520-6761

Likert scale has been also used to measure the ranking position of each attribute rating scale ranging from not important to very important ( 1 to 5 ) has been used and asked to encircle the score to express their opinion. For finding out the psychological and demographic factors, these are also six sensitive questions are mentioned in the questionnaires. A total of 1100 questionnaires were distributed to the people who were the target respondents of this study. 912 respondents were received, of which 840 were completed and usable. So, finally, 840 questionnaires have been used for the analysis purpose.

\subsection{Data Analysis Procedures}

Some descriptive statistics (average, percentages) have been used to evaluate the current situation of the telecommunication sectors in Bangladesh. Data on demographic variables - gender, age, and profession were processed and reported through descriptive analysis. The opinion of the respondents has been analyzed in light of the analysis procedures used by Mertin Fishbein's Multi-attribute Attitude Model for measuring the attitude of consumers towards the object.

\section{Findings and Analysis}

Both Univariate and Multivariate Analysis used to analyze the data. Univariate analysis is used as a statistical approach for evaluating the Socio-demographic characteristics of the respondent and weighted average of the considerable intrinsic and extrinsic attributes of the telecommunication service. The multivariate analysis technique used to identify the more preferred telecommunication brand on the basis of consumers' response.

\subsection{Respondents Demographic Data}

The analysis and findings of the respondents' demographics are shown in Table 3 through the frequency distribution method.

Table 3. Respondents' demographic information

\begin{tabular}{|c|c|c|c|c|}
\hline \multirow{2}{*}{ Age } & \multicolumn{3}{|c|}{ Number of the Consumers } & $\begin{array}{c}\text { Percentage (\%) of the } \\
\text { Consumers }\end{array}$ \\
\cline { 2 - 5 } & Male & Female & Total & 64.3 \\
\hline $18-25$ & 412 & 128 & 540 & 22.1 \\
\hline $26-35$ & 136 & 50 & 186 & 11.4 \\
\hline $36-45$ & 81 & 15 & 96 & 1.8 \\
\hline $46-55$ & 6 & 9 & 3 & .4 \\
\hline $56-65$ & 2 & 1 & 840 & 100 \\
\hline Total & 637 & 203 & 3 & \\
\hline
\end{tabular}

\begin{tabular}{|l|c|c|}
\hline \multicolumn{1}{|c|}{ Profession of the Respondents } & Number of the Consumers & Percentage (\%) of the Consumers \\
\hline Student & 557 & 66.3 \\
\hline University Teacher & 35 & 4.2 \\
\hline Banker & 29 & 3.5 \\
\hline Businessman & 66 & 7.9 \\
\hline Corporate Officer & 28 & 3.3 \\
\hline Government Employees & 29 & 3.5 \\
\hline Non-government Employees & 50 & 6.0 \\
\hline Housewife & 46 & 5.5 \\
\hline Total & 840 & 100 \\
\hline
\end{tabular}

Source: Neger, M. (2018), PhD Thesis (unpublished)

From Table 3, the study reveals that $86.4 \%$ of respondents are in age 18 to 35 from where $75.48 \%$ are male. Moreover, about $66 \%$ of the respondents are students of the tertiary levels who have adaptable capability about sophisticated technology and also aware of market change.

\subsection{Consumers Overall Perceptions about Telecommunication Services}

Network availability, service quality, service charge strategies, brand image and offered values are the five determinant of changing the consumers' perception of their current brand. This section is going to determine the rank of those determinants of the telecommunication sectors in Bangladesh using a weighted average or the basis of intrinsic and extrinsic attributes. 
Table 4. Consumes consideration based on intrinsic and intrinsic attributes for using telecommunication service

\begin{tabular}{|l|c|c|c|c|c|c|c|}
\hline \multicolumn{1}{|c|}{$\begin{array}{c}\text { Attributes } \\
\text { (Internal/ } \\
\text { External) }\end{array}$} & $\begin{array}{c}\text { Unimportant } \\
\text { (1) }\end{array}$ & $\begin{array}{c}\text { Quite } \\
\text { Unimportant } \\
\text { (2) }\end{array}$ & $\begin{array}{c}\text { Neither } \\
\text { Important nor } \\
\text { Unimportant (3) }\end{array}$ & $\begin{array}{c}\text { Important } \\
\text { (4) }\end{array}$ & $\begin{array}{c}\text { Very } \\
\text { Important (5) }\end{array}$ & $\begin{array}{c}\text { Weighted } \\
\text { Average }\end{array}$ & Ranks \\
\hline $\begin{array}{l}\text { Network } \\
\text { Availability }\end{array}$ & 8 & 42 & 75 & 91 & 624 & 4.5250 & 1 \\
\hline Service Quality & 9 & 22 & 124 & 374 & 311 & 4.1381 & 2 \\
\hline $\begin{array}{l}\text { Service Charge } \\
\text { Strategies }\end{array}$ & 22 & 41 & 156 & 294 & 327 & 4.0274 & 3 \\
\hline Brand Image & 34 & 72 & 232 & 259 & 243 & 3.7202 & 5 \\
\hline Offered Value & 51 & 88 & 167 & 208 & 326 & 3.7976 & 4 \\
\hline
\end{tabular}

Source: Neger, M. (2018), PhD Thesis (unpublished)

$\mathrm{WA}=\frac{\sum W i x i}{\sum W i}$

Where $X_{1}$ is the score ( 1 to 5 ) for each response and Wi is the corresponding weight (score frequency)

Table 4 reveals that all the respondents consider five attributes, which affect on consumer behavior for using telecommunication service. On the five attributes, "network availability" is considered as the highest importance where the weighted average is 4.525 for the attribute. The other important attributes are i) Service quality (weighted average being 4.13), ii) Service charge strategies (weighted average being 4.02), iii) Offered value (weighted average being 3.79), and iv) Brand image (weighted average being 3.72).

\subsection{Consumers' Attitude towards Telecommunication Operators in Bangladesh: A Fishbein's Multiattribute Attitude Model Approach}

Total Number of Mobile Phone Subscriptions was 156.469 million at the end of October, 2018 (http:// www.btrc.gov.bd/content/mobile-phone-subscribers-bangladesh-october-2018). Among the total operators, 97.604\% mobile phone subscribers belong to three operators namely, Grameen Phone LTD. (GP), Banglalink Digital Communications Limited, Robi Axiata Limited (Robi). Hence, Fishbein's Multiattribute Attitude Model has been applied to evaluate consumers' attitude among Grameen Phone Ltd. (GP), Banglalink Digital Communication Limited, Robi Axiata Limited (Robi) operators.

Table 5. Fishbein's Multiattribute Attitude Model for measuring consumers' attitude towards three telecommunication operators in Bangladesh

\begin{tabular}{|c|c|c|c|c|c|c|c|c|c|}
\hline \multirow[t]{2}{*}{ Affection Items } & \multicolumn{3}{|c|}{ Grameen Phone } & \multicolumn{3}{|c|}{ Banglalink } & \multicolumn{3}{|c|}{ Robi } \\
\hline & $\mathbf{e}_{\mathbf{i}}$ & $\mathbf{b}_{\mathbf{i}}$ & $\mathbf{e}_{\mathbf{i}} \mathbf{b}_{\mathbf{i}}$ & $\mathbf{e}_{\mathbf{i}}$ & $\mathbf{b}_{\mathbf{i}}$ & $\mathbf{e}_{\mathbf{i}} \mathbf{b}_{\mathbf{i}}$ & $\mathbf{e}_{\mathbf{i}}$ & $\mathbf{b}_{\mathbf{i}}$ & $\mathbf{e}_{\mathbf{i}} \mathbf{b}_{\mathbf{i}}$ \\
\hline $\begin{array}{l}\text { Network } \\
\text { Availability }\end{array}$ & 2.2560 & 5.4881 & 12.381 & 1.3929 & 4.8536 & 6.761 & 1.2881 & 4.7869 & 6.166 \\
\hline Service Quality & 1.4226 & 4.7512 & 6.759 & 1.1905 & 4.4821 & 5.336 & 1.1214 & 4.4190 & 4.955 \\
\hline $\begin{array}{l}\text { Service Charge } \\
\text { Strategies }\end{array}$ & .1060 & 3.7690 & 0.400 & .8940 & 4.2583 & 3.807 & .9167 & 4.2821 & 3.925 \\
\hline Brand Image & 1.6345 & 4.9131 & 8.031 & 1.3512 & 4.5429 & 6.138 & 1.2107 & 4.5357 & 5.491 \\
\hline Offered Value & .5583 & 4.0512 & 2.262 & .9488 & 4.2179 & 4.002 & 1.0131 & 4.2155 & 4.271 \\
\hline$A_{0}=\sum e i b i$ & & & 29.833 & & & 26.044 & & & 24.808 \\
\hline
\end{tabular}

Source: Neger, M. (2018), PhD Thesis (unpublished)

From the Fishbein's Model, Overall position of consumers' attitude towards the individual object based on different attributes can be evaluated. The strength of belief (bi) is the $\mathrm{i}^{\text {th }}$ value of the salient belief about individual attribute for each object. The evaluation of the importance of the attributes (belief evaluation, ei) reflects how favorably consumers perceived the attributes (Table 5). It is clear from the table that attitude of different telecommunication service providing firms on the basis of Fishbein's Multiattribute Attitude model is 29.833, 26.044 and 24.808 for Grameen Phone Ltd. (GP), Banglalink Digital Communications Limited, Robi Axiata Limited (Robi) respectively (Table 5).

The findings from Fishbein's Multiattribute Attitude model has been suggested that GP is viewed top most favorable position on all desired attributes because it was received total value 29.833 for the attitude towards the object (GP). Banglalink Digital Communications Limited has the next position selected by respondents. 
After that Robi Axiata Limited (Robi) is the last position among the three selected firms by using consumers' rating.

\section{Recommendations and Conclusions}

Based on the findings we put forward the following recommendations:

a) Operators of the telecommunication sector should have quick expansion in network development with the 4G network with video calling facility as early as possible.

b) Telecommunication service providers should monitor their activities and take initiative to improve both intrinsic and extrinsic attributes of service in comparison to competitors' firms.

c) The managers can take various strategies such as, maintain and develop these attributes, operate strong advertisement for gaining a competitive advantage based on service differentiation. Besides, manufacturers of different firms can follow all possible attitudes change strategies, which add new salient belief about the attitude towards telecommunication service ideally one with a positive. Increase the strength of an existing belief more salient.

d) Managers of telecommunication firms should study their target market precisely and recognize customers' attitudes and their expectations, what they really want and how they can be satisfied. Having a loyalty programme to recognize frequent customers can bring a competitive advantage for the telecommunication service providing firms in Bangladesh. They need some strategic alliances and joint ventures to have other telecommunication service related partners.

Conclusively, the study has employed to identify consumers' attitude towards telecommunication service based on Fishbein's Multi-attributes Attitude Model. This Model has been applied for three telecommunication service-providing firms, which provide wide service in Bangladesh. A considerable five attributes have been selected as determinates of firm choice. The result has been reported here strongly to support that the consumers' attitude is related to the attitude measurements based upon beliefs about and relative importance of service or product-specific attributes. Grameen Phone Ltd. is the telecommunication service providing firm, bears the highest attitude of consumers; Banglalink and Robi are next popular respectively for telecommunication service in Bangladesh as per the opinions of the consumers. The results of the weighted average indicate that network availability is a more important attribute to the consumer for receiving telecommunication service. The findings highlight the need to gain an understanding of the impacts of both intrinsic and extrinsic attributes and their contribution to the brand preferences individually. Finally, it can be said that though there are some limitations of the study it might be an effective avenue for the service providers of telecommunication service to measure the attitude towards the object. Without measuring the actual perception of consumers on different attributes of telecommunication service that are usually considered by consumers in Bangladesh it can affect the marketing process for the said service providing firms.

\section{Limitations and Directions for Further Research}

This study spawns a number of limitations and potential fertile directions for future research. The study reveals that some attributes are considered for measuring consumers' attitude towards telecommunication firms, which have the strength of belief (bi) that always may not be true. There might be more attributes like internal package variation of different brand and its availability, internet facility of the different brand that are not considered in the study. Therefore, further research may be conducted to assess services benefits and risks of each attribute of telecommunication service considering more attributes related to the object.

Besides, the major limitation of this study is that the study attempts to consider only three leading telecommunication firms. It would have been more representatives if the total number of telecommunication service providing firms of Bangladesh could have been taken under this study. But it is not possible by the researcher due to the financial and time constraints. It is the responsibility of the future researchers to overcome these shortcomings.

Next, $5.5 \%$ of housewives are considered as a sample, almost among did not fully aware of telecommunication service. They provided their opinion based on their likely most one and willingly they are not interested to answer the questionnaire. This is especially important for manufacturers who need to determine whether the telecommunication service providing firms and attributes of telecommunication service shown in this study were limited to these populations due to not taking the opinion from unconscious and illiterate housewives etc. 
Lastly, Fishbein's Multiattribute Attitude model has been used for measuring consumers' attitude towards the telecommunication service in this study. Unfortunately, a high level of academic research effort expanded on this model was not reflected in the actual use of managers to assist the decision making and planning. Traditionally, the researchers have argued that a useful focus on research is to provide the description of a complex process that would aid in the systematic examination of that process and highlight areas of further research. Besides, Fishbein's model could not explain how a consumer leads to a certain buying behavior, introduces normative influences into the overall model and a causal relationship between the two antecedents and intention. In addition, where macro-marketing influence is higher, how a consumer can take the decision has not given the avenue in this model.

\section{References}

1. Anderson, Eugene W., Claes, Fornell and Sanal, K. Mazvanchery (2004). Customer Satisfaction and Shareholder Value. Journal of Marketing Research, 68, 172-185.

2. Aaker (1994). Effects of intangible factors and multi-attribute product evaluations. Journal of Consumer Research, 13, 148-152.

3. Abdullah, S.S. and Rakibul, H. (2015). Factors Influencing the Behavior of the Mobile Phone Uses to Switch their Mobile Telecommunication Operators in Bangladesh. International Journal of Trade \& Commerce, 4(1), 15-26.

4. Ajzen, Leek and Fishbein, Martin (1980). Understanding Attitudes and Predicting Social Behavior. Englewood Clifs, N.J.: Prentice-Hall.

5. Albert, R. Wildt, Albert V. Bruno, James L. Gintes (1981). Attitudes Model. Journal of Advertising Research, 21(4), 112-121.

6. Ali, B., Iris, R., Rajiv, S., Joseph, A. (2019). Mobile technology identity and self-efficacy: Implications for the adoption of clinically supported mobile health apps. International Journal of Information Management, 49, 58-68.

7. Ashsaf, I., and Kumar, A. (1913). Enhancing Competitive Advantage on Cellular Industry in Pakistan. Journal of Consumer Marketing, 20(5), 430-440.

8. Bearden, William, O., and Terence, A. Shimp (1982). The Use of Extrinsic Cues to Facilitate Product Adoption. Journal of Marketing Research, 19, 229-239.

9. Beleh (1998). Situational Variables and Consumer Behavior. Journal of Consumer Research, 4, 90-101.

10.Chawdhury, H.K. (2001). Generalizability of Perceived Quality Measures: An Evaluation. Yokohama Journal of Social Sciences, 6(1), 27-38.

11.Churchill, Gilbert, A. and Peter, P.J. (1984). Marketing Research: Methodological Foundations. Sixth Edition the Dryden Press, Harcourt Brac College Publishers.

12.De Chernatony and Mc Donald (1998). Measurement of Brand Attitudes of Brands Loyal towards the Object. Advances in Consumer Research, 13, 330-340.

13.Dodds, W. B., and Kent, B. Monroe (1991). Factors affecting in consumers, decision making for receiving service. Journal of Marketing Research, 30, 205-216.

14.Engel, F. James, Roger, D. Blackwell, Paul, W. Miniard (1990). Consumer Behavior. Sixth Edition. The Dryden Press. A division of Holt, Rincart and Winston Inc.

15.Erickson, Gary M., Johny, K. Johansson and Cha Paul (1984). Image Variables in Multiattribute Product Evaluations: Country-of-orgin Effects. Journal of Consumer Research, 11, 694-699.

16.Erickson, Gary M. and Johny, K. Johansson (1985). The Role of Price in Multi-Attribute Product Evaluation. Journal of Consumer Research, 12, 195-199.

17.Feigenbaum (1951). An evaluation of the service quality, which affect on attitude. Journal of Marketing, 40, 30-40.

18.Fishbein, M. (1963). An Investigation of Relationship between Beliefs about an Object and Attitude towards that Object. Human Relations, 16, 233-240.

19.Fishbein, M. and Ajzen (1975). Attitudes toward objects and predictors of single and multiple behavioral criteria. Psychological Review, 81(1), 59-74.

20.Hasan (2013). Factors influencing to Bangladeshi consumers' mobile phone operators choice and change behavior. Journal of Economics and Sustainable Development, 4(2), 159-197. Available at: http:// www.btrc.gov.bd/content/mobile-phone-subscribers-bangladesh-october-2018.

21.Izogo, E.E. (2015). Determents of attitudinal loyalty in Nigerian telecom service sector: does commitment play a mediating role? Journal of Retailing and Consumer Services, 23, 107-117.

22.Izogo, E.E. (2017). Customer loyalty in telecom service sector: The role of service quality and customer commitment. TQM Journal, 29(1), 1-18. 
23.Kothari, C. R. (2003). Research Methodology: Methods and Techniques. Second Edition; Wishwa Prakashan; New Delhi; 2003; EN.

24.Loudon, David and Bitta, Albert J. Della (1988). Consumer Behavior: Concepts and Applications. 3rd ed; New York: McGra-Hill Book Company.

25.Monroe, K.B. and Krishnan, R. (1976). The effect of price on subjective evaluations, in Jacoby, J. and Olson, J. (Eds), Perceived Quality, Lexing ton Books, Lexington, MA.

26.Neger, M. (2011). Measuring Consumers' Attitude towards Internet Service: A study on Selected Firms in Bangladesh. ASA University Review, 5(1), (January-June), 275-283.

27.Neger, M. (2018). Consumers' Attitude towards Brand Switching: A Study on Telecommunication Sector in Bangladesh. PhD Thesis (unpublished).

28.Prasad, M. and Prasanna, K. (2016). Factors influencing the behavior of the mobile phone users to switch their service providers in Andhra Pradesh. Global Journal of Management and Business Research: E Marketing, 16(5), 23-32.

29.Sciffman, Leon, G. and Kanuk, Lealie Lazan (1994). Consumer Behavior, 5th ed., New York: Prentic Hall International, Inc.

30.Taher (1998). Attitude of Owners, Mangers, and Works: A Case Study in Bangladesh, an Unpublished Research Paper.

31.Umar, S., Emmanuel, I.Y. (2014). Institutions, Telecommunications and Economic Performance in Nigeria. Journal of Economics and Sustainable Development, 5(18), 10-122.

32. Yousef, M. and Zerehkafi, H. (2013). Customers Attitude toward Mobile Service Provides in Hyderabad. IOSR Journal of Computer Engineering, 11(6) (May-June), 83-88. 